\title{
Study on effects of microbial fermented soyabean meal on production performances of sows and suckling piglets and its acting mechanism
}

\author{
P. Wang1, C.G. Fan', J. Chang', Q.Q. Yin ${ }^{1,5}$, A.D. Song'2, X.W. Dang ${ }^{3}$ and F.S. Lư \\ Henan Agricultural University \\ ${ }^{1}$ College of Animal Science and Veterinary Medicine, ${ }^{2}$ College of Life Science, Zhengzhou 450002, China \\ ${ }^{3}$ Henan Delin Biological Product Co. Ltd., Xinxiang 453000, China \\ ${ }^{4}$ Henan Engineering and Technology Research Center of Feed Microbes, Zhoukou 466000, China
}

KEY WORDS: sows, suckling piglets, fermented soyabean meal, production performance, acting mechanism

Received: $\quad 25$ April 2014

Revised: 25 November 2015

Accepted: $\quad 10$ March 2016

${ }^{5}$ Corresponding author:

e-mail: qqy1964@126.com

\begin{abstract}
Thirty-two crossbred (Large White $\times$ Landrace) gestating sows were used to study the effects of fermented soyabean meal (FSBM) on their reproduction performance and piglet production. Sows were randomly divided into four groups and fed diets containing 0, 5, 10 and 15\% FSBM replacing the same amount of soyabean meal, respectively. The experimental periods lasted 58 days including 30 days of pre-farrowing and 28 days of post-farrowing. The results showed that nutrient digestibility of lactating sows as well as survival rate of suckling piglets were improved by FSBM additions during lactation $(P<0.05)$, but without significant effect on sow's reproduction during pregnancy $(P>0.05)$. The results also showed that non-fat milk solids, protease activity and lactic acid bacteria counts in sow's faeces, total antioxidant capacity, superoxide dismutase activity, glutathione and prolactin concentrations in lactating sow's serum were significantly increased $(P<0.05)$, while serum cholesterol and urea nitrogen concentrations, as well as phosphocreatine kinase and aspartate aminotransferase activities were decreased with FSBM addition $(P<0.05)$. It could be concluded that $10-15 \%$ FSBM addition in lactating sow's diets could increase sow's reproduction and piglet production.
\end{abstract}

\section{Introduction}

Due to its high protein content and relatively well-balanced amino acid profile, soyabean meal (SBM) has been traditionally used as an important source of dietary protein in the feed industry (NRC, 1998; Teng et al., 2012). However, SBM contains antinutritional factors such as trypsin inhibitor, phytic acid, antigenic proteins (glycinin (11S) and $\beta$-conglycinin (7S)) etc., which can injure mucous membrane in duodenum and jejunum ( $\mathrm{Li}$ et al.,
1991), reduce nutrient availability and depress animal growth performance and health status (Yen et al., 1977). As a result, the wide application of SBM in animal production is limited, especially for young animals (Baker et al., 2010).

Fermented soyabean meal (FSBM) is manufactured through fermentation of SBM with beneficial microbes such as yeast, lactic acid bacteria, and Bacillus subtilis (Kiers et al., 2003). Microbial fermentation can effectively eliminate 
antinutritional factors, hydrolyse proteins to small peptide and amino acids to some extent, produce large amount of enzymes and probiotics, which have a positive effect on animal health and production (Lee et al., 2007; Song et al., 2010; Gao et al., 2013). FSBM has both high biological values and probiotic functions, so its application will become more extensive.

Even though many researches have proved the positive effects of FSBM on animal production performance, FSBM application has some limits because its price is higher than SBM. Therefore, the ideal application fields of FSBM may be as such: 1. for the young or sick animals because their digestive tracts are underdeveloped or dysfunctional to degrade the antinutritional factors and digest nutrients effectively, 2 . in the special feeding periods with large economic profits, such as lactating period or later pregnancy period, etc. Sow's lactating and later pregnancy periods are very important for piglet growth and the further production; however, only few reports are focused on FSBM application in sow's diets. This research focuses on the effect of FSBM on sow's reproduction and their maternal functions for piglet production as well as its acting mechanism.

\section{Material and methods}

\section{Preparation of fermented soyabean meal (FSBM) and analyses of antigenic protein and amino acid concentrations}

Soyabean meal (SBM) (97\%), maize meal (2\%) and glucose $(1 \%)$ were mixed with water at 2:1 ratio $(\mathrm{w} / \mathrm{v})$, which was autoclaved at $120^{\circ} \mathrm{C}$ for $20 \mathrm{~min}$, cooled at room temperature, and then three species of microbes (Bacillus subtilis, Hansenula anomala and Lactobacillus casei with $1 \times 10^{9}$ colony forming units $(\mathrm{CFU}) \cdot \mathrm{ml}^{-1}$ for each species mixed at 2:1:2 ratio) were added by $5 \%(\mathrm{v} / \mathrm{w})$ according to the previous report (Fan, 2013). SBM was fermented at $37{ }^{\circ} \mathrm{C}$ for $48 \mathrm{~h}$, and dried at $45-50{ }^{\circ} \mathrm{C}$. The dried products were ground through a $2 \mathrm{~mm}$ mill and stored at dry environments. The antigenic proteins were analysed as followed: FSBM and SBM were soaked in extracting buffer $(0.05 \mathrm{M}$ Tris-HCL buffer, $\mathrm{pH}$ 9.0) at liquid-to-solid ratio of 10:1 for $2 \mathrm{~h}$ in $55{ }^{\circ} \mathrm{C}$ water bath, and then centrifuged at $9000 \mathrm{~g}$ for $30 \mathrm{~min}$ at $4{ }^{\circ} \mathrm{C}$. The obtained supernatant was used for the further analysis. Molecular weight of antigenic proteins was analysed using sodium dodecyl sulphate polyacrylamide gel electrophoresis (SDS - PAGE) that was carried out according to the previous method (Yin et al., 2007). Amino acid concentrations in FSBM and SBM were determined with automatic amino acid analyser (Model L-8800; Hitachi High-Technologies Corporation, Tokyo, Japan).

\section{Experimental design and animal management}

Thirty-two crossbred (Large White $\times$ Landrace) gestating sows of the same age, body condition and parity were used in the trial. They were randomly divided into 4 groups, of 8 sows each. The SBM was replaced with FSBM at 0, 5, 10 and $15 \%$ levels. The feeding standards of sows were referred to NRC (1998). The diet compositions and nutrient levels were listed in Table 1.

The experimental periods lasted 58 days ( 30 days of pre-farrowing and 28 days of post-farrowing). The sows were kept in pens with slotted floor, with room temperature of $23-28{ }^{\circ} \mathrm{C}$ with $60-65 \%$ humidity during gestation and lactation. The suckling piglets were kept in another box with temperature of $32-34{ }^{\circ} \mathrm{C}$ at the first week of life, and then the temperature was decreased about $2-3{ }^{\circ} \mathrm{C}$ weekly.

Feed and water were given to sows ad libitum. Suckling piglets were offered creep diet freely from 7 day of life until weaning at day 28. Piglets were weighed at birth and weaning. The diarrhoea incidences and mortality of piglets were recorded daily, when feed intake in each group was recorded once a week.

\section{Chemical analyses}

The apparent digestibility of nutrients was determined by the inner indicator of acid-insoluble ash (AIA) method (McCarthy et al., 1974; Atkinson et al., 1984). Faeces were collected separately during a period of 3 consecutive days. Collections were made twice a day, and the faeces of each sow were pooled, dried and sampled for measuring apparent nutrient digestibility. In the diets and faeces samples the crude protein (CP) and ether extract (EE) contents were analysed using the AOAC International (2011) methods No. 984.13 and 920.39, respectively. Calcium $(\mathrm{Ca})$ was determined with potassium permanganate $\left(\mathrm{KMnO}_{4}\right)$ method and phosphorus (P) was determined with ammonium molybdate $\left(\left(\mathrm{NH}_{4}\right)_{6} \mathrm{Mo}_{7} \mathrm{O}_{24}\right)$ method (Jurgens, 1997).

Digestibility was calculated using equation: nutrient apparent digestibility $=100-(100 \times$ indicator content in feed / indicator content in faeces $\times$ nutrient content in faeces / nutrient content in feed). 
Table 1. Ingredients, chemical composition and nutritive value of diets, $\%$

\begin{tabular}{|c|c|c|c|c|}
\hline Indices & $\begin{array}{l}\text { Control } \\
\text { group }\end{array}$ & $\begin{array}{l}5 \% \\
\text { FSBM }^{1}\end{array}$ & $\begin{array}{l}10 \% \\
\text { FSBM }\end{array}$ & $\begin{array}{l}15 \% \\
\text { FSBM }\end{array}$ \\
\hline \multicolumn{5}{|l|}{ Ingredients } \\
\hline maize meal & 65 & 65 & 65 & 65 \\
\hline FSBM & 0 & 5 & 10 & 15 \\
\hline $\mathrm{SBM}^{2}\left(43 \% \mathrm{CP}^{3}\right)$ & 0.00 & 0 & 10.5 & 4 \\
\hline SBM $(46 \%$ CP) & 20.6 & 15 & - & - \\
\hline wheat bran & 9.4 & 10 & 9.5 & 11 \\
\hline soyabean oil & 1 & 1 & 1 & 1 \\
\hline $\mathrm{NaCl}$ & 0.5 & 0.5 & 0.5 & 0.5 \\
\hline $\mathrm{CaCO}_{3}$ & 1.52 & 1.52 & 1.52 & 1.52 \\
\hline $\mathrm{CaHPO}_{4}$ & 1.04 & 1.04 & 1.04 & 1.04 \\
\hline L-lysine & 0.26 & 0.25 & 0.26 & 0.25 \\
\hline DL-methionine & 0.06 & 0.07 & 0.06 & 0.07 \\
\hline premix & 0.62 & 0.62 & 0.62 & 0.62 \\
\hline \multicolumn{5}{|l|}{ Chemical composition } \\
\hline digestible energy, $\mathrm{MJ} \cdot \mathrm{kg}^{-1}$ & 13.35 & 13.39 & 13.41 & 13.44 \\
\hline crude protein & 16.48 & 16.50 & 16.53 & 16.47 \\
\hline ether extract & 3.95 & 3.96 & 3.93 & 3.97 \\
\hline $\mathrm{Ca}$ & 0.81 & 0.79 & 0.80 & 0.83 \\
\hline total $P$ & 0.64 & 0.63 & 0.61 & 0.65 \\
\hline lysine & 1.03 & 1.03 & 1.03 & 1.03 \\
\hline methionine & 0.31 & 0.31 & 0.30 & 0.31 \\
\hline methionine + cysteine & 0.58 & 0.58 & 0.58 & 0.58 \\
\hline \multicolumn{5}{|l|}{ Digestible } \\
\hline protein & 14.42 & 14.93 & 15.02 & 15.24 \\
\hline ether extract & 2.70 & 3.10 & 3.20 & 3.17 \\
\hline $\mathrm{Ca}$ & 0.43 & 0.46 & 0.49 & 0.60 \\
\hline$P$ & 0.42 & 0.44 & 0.43 & 0.51 \\
\hline
\end{tabular}

${ }^{1}$ FSBM - fermented soyabean meal; ${ }^{2}$ SBM - soyabean meal; ${ }^{3} \mathrm{CP}$ - crude protein; ${ }^{4}$ supplied per kg of complete diet: IU: vit. A 11760 , vit. D 3880; mg: vit. $E 66$, vit. $K 34.0$, vit. $B_{1} 2.0$, vit. $B_{2} 8.0$, vit. $B_{3} 16.2$, vit. $B_{6} 2.94$, vit. $B_{12} 0.02$, nicotinic 22.4 , pantothenate 16 , biotin 0.4 , Fe 80, Mn 28.8, Cu 16, Zn 80, Se 0.32; g: choline 0.5

\section{Milk analysis}

Milk samples were collected from 5 sows in each group on the 21 day of lactation. Two ml of milk were collected from each teat of lactating sow, pooled and stored at $-20{ }^{\circ} \mathrm{C}$ until determining milk composition (fat, protein, lactose, non-fat milk solid) with a near infrared milk analyser (Lacto star 1; Gerber, Berlin, Germany).

\section{Serum biochemical parameters analysis}

At the end of the lactation period, blood samples were taken from 5 lactating sows in each group, and centrifuged at $3000 \mathrm{~g}$ for $5 \mathrm{~min}$ after clotting. The serum was stored at $-20{ }^{\circ} \mathrm{C}$ until serum biochemical determination. The serum biochemical parameters (content of total protein, glucose, triglycerides, total cholesterol, urea nitrogen, creatinine, immunoglobulin (Ig) A, IgG, and IgM, activity of phosphocre- atine kinase, alanine and aspartate aminotransferase) were analysed with an automatic biochemistry analyser (model 7170A; Hitachi High-Technologies Corporation, Tokyo, Japan). Prolactin was determined by an automated chemiluminescence system (DXI800; Beckman Coulter Inc., Brea, California, USA). Serum antioxidant indices such as total antioxidant capacity (T-AOC, Cat. No A015), superoxide dismutase (SOD) activity (Cat. No. A001-1) and glutathione (GSH) content (Cat. No. A005) were measured by the commercially available kits (Nanjing Jiancheng Bioengineering Institute, Nanjing, China).

\section{Determination of microbial counts and enzyme activity in faeces}

Fresh faecal samples from 5 lactating sows in each group were collected without contamination for microbial and enzyme analyses. Faecal samples were serially diluted from $10^{-1}$ to $10^{-8}$ with $0.9 \%$ physiological saline for $E$. coli and with anaerobic solution for lactic acid bacteria (Shapton and Board, 1971), and then vortexed completely. The mixtures $(0.1-0.2 \mathrm{ml})$ were dispensed onto the plates with eosin methylene blue agar for determining $E$. coli or into anaerobic roll tubes with MRS agar for determining lactic acid bacteria (Hartemink et al., 1997). The bacteria were incubated for 2 days at $37^{\circ} \mathrm{C}$, and then $\mathrm{CFU} \cdot \mathrm{g}^{-1}$ was used to express microbial counts calculated as logarithm $(1 \mathrm{~g})$ value.

Faecal samples were homogenized with sterile water, and then centrifuged at $5000 \mathrm{~g}$ for $20 \mathrm{~min}$ at $4{ }^{\circ} \mathrm{C}$ to obtain the supernatant for analysing different enzyme activities. Amylase activity was assayed with $2 \%(\mathrm{w} / \mathrm{v})$ starch solution as substrate (Rick and Stegbauer, 1974). Protease activity was measured by a modification of the method by using azocasein as a substrate (Lynn and ClevetteRadford, 1984). Lipase activity was measured according to the method Erlanson-Albertsson et al. (1987). One enzyme unit is defined as the activity that hydrolyses $1 \mu \mathrm{mol}$ substrate per min.

\section{Statistical analysis}

Experimental data were expressed as the mean and standard errors. The data were analysed using the analysis of variance (ANOVA) procedures of Statistical Analysis Systems Institute (SAS 6.0; 2012, SAS Institute Inc., Cary, NC, USA). Duncan's multiple range test was used to compare treatment means. Differences were considered statistically significant at $P<0.05$. 


\section{Results}

\section{Nutrient and antigen protein analyses in fermented soyabean meal (FSBM)}

Crude protein, acid-soluble protein, lactic acid, Bacillus subtilis, Lactobacillus casei and Hansenula anomala were higher in FSBM than in soyabean meal (SBM) as a result of microbial fermentation (Table 2). Amino acid analysis indicated that the concentrations of most amino acids except glycine, alanine and methionine were increased in FSBM, when compared with SBM. There was almost no band for the FSBM except one from market, inferring that a lot of antigenic proteins (glycinin and betaconglycinin) are degraded by microbial fermentation and enzymatic hydrolyses (Figure 1).

\section{Production performance of sows and suckling piglets}

Feed intake of lactating sows fed 15\% FSBM was increased, when compared with the control and 5\% FSBM groups $(P<0.05$; Table 3$)$. It was observed that FSBM addition during 30 days of gestation had no significant effect on reproductive

Table 2. Nutrient compositions of SBM and FSBM, \% of dry matter

\begin{tabular}{|c|c|c|}
\hline Indices & SBM & FSBM \\
\hline Crude protein & 53.23 & 57.07 \\
\hline Acid-soluble protein & 6.49 & 15.05 \\
\hline Ash & 7.44 & 7.93 \\
\hline $\mathrm{Ca}$ & 0.37 & 0.41 \\
\hline Total P & 0.71 & 0.76 \\
\hline Lactic acid & 0 & 3.47 \\
\hline Bacillus subtilis, CFU ${ }^{1} \cdot \mathrm{g}^{-1}$ & 0 & $2.0 \times 10^{6}$ \\
\hline Lactobacillus casei, CFU · $\mathrm{g}^{-1}$ & 0 & $1.0 \times 10^{6}$ \\
\hline Hansenula anomala, CFU $\cdot \mathrm{g}^{-1}$ & 0 & $0.76 \times 10^{6}$ \\
\hline Lysine & 3.16 & 3.45 \\
\hline Methionine & 0.70 & 0.69 \\
\hline Aspartic acid & 6.10 & 6.39 \\
\hline Threonine & 2.10 & 2.28 \\
\hline Serine & 2.81 & 2.98 \\
\hline Glutamic acid & 10.50 & 11.20 \\
\hline Glycine & 2.57 & 2.35 \\
\hline Alanine & 2.65 & 2.46 \\
\hline Cysteine & 0.55 & 0.63 \\
\hline Valine & 2.33 & 2.72 \\
\hline Isoleucine & 2.35 & 2.55 \\
\hline Leucine & 3.94 & 4.35 \\
\hline Tyrosine & 1.65 & 1.79 \\
\hline Phenylalanine & 2.86 & 3.21 \\
\hline Histidine & 1.39 & 1.43 \\
\hline Arginine & 3.45 & 4.01 \\
\hline Proline & 2.73 & 2.77 \\
\hline Total amino acids & 51.84 & 55.30 \\
\hline
\end{tabular}

${ }^{1} \mathrm{CFU}$ - colony forming units

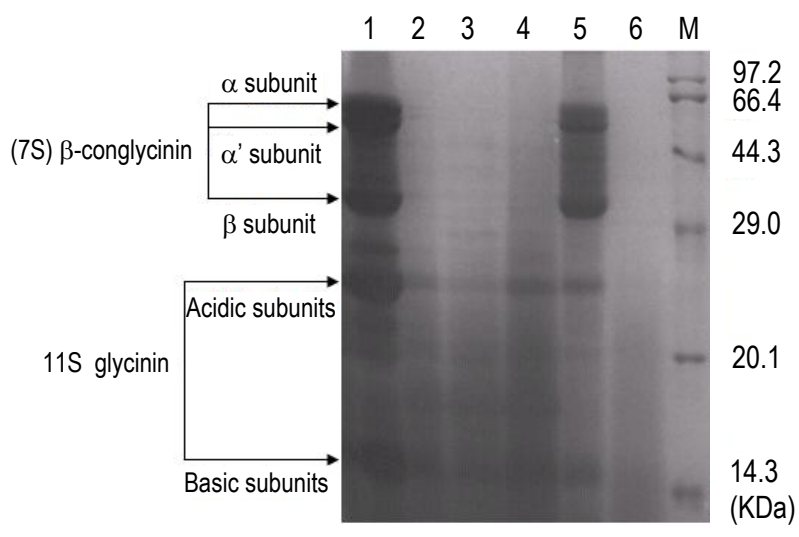

Figure 1. Image of proteins separation from SBM and FSBM with use of sodium dodecyl sulphate polyacrylamide gel electrophoresis (SDSPAGE). Lane M: protein marker (3450; TaKaRa, Dalin, China); Lane 1: SBM; Lane 2-4: FSBM produced for this study; Lane 5-6: FSBM commercially available on the market

parameters such as piglet survival rate, litter weight, or individual piglet weight at birth $(P>0.05)$. However, the number of weaned piglets and survival rate during suckling were higher in 3 groups containing FSBM than the control group $(P<0.05)$. The other parameters such as diarrhoea incidences and daily gain of piglets were not significantly different among 4 groups $(P>0.05)$.

\section{Nutrient digestibility and milk composition}

The apparent digestibility of crude protein, ether extract, calcium and phosphorus (Table 4) in the groups with added FSBM was higher than in the control group $(P<0.05)$. The addition of $15 \%$ FSBM had the best effect on digestibility of crude protein, calcium and phosphorus when compared with 3 other groups $(P<0.05)$. Only 15\% FSBM addition could significantly increase the concentration of nonfat milk solids when compared with 3 other groups $(P<0.05$; Table 5$)$. The other milk parameters such as protein, fat and lactose concentrations were not significantly different among 4 groups $(P>0.05)$.

\section{Effect of FSBM on serum biochemical parameters of lactating sows}

FSBM addition significantly increased serum T-AOC, SOD activity, and GSH and prolactin concentrations $(P<0.05)$, while decreased serum urea nitrogen and total cholesterol contents, phosphocreatine kinase and aspartate aminotransferase activities $(P<0.05)$, when compared with the control group (Table 6). FSBM had no significant effect on other serum parameters such as total protein, glucose, triglyceride and creatinine concentrations, alanine aminotransferase activity, and $\operatorname{IgA}, \operatorname{IgG}$ and $\operatorname{IgM}$ contents $(P>0.05)$. 
Table 3. Effects of FSBM on sow's performance

\begin{tabular}{lcccc}
\hline Indices & Control group & \multicolumn{1}{c}{$5 \% \mathrm{FSBM}$} & $10 \% \mathrm{FSBM}$ & $15 \% \mathrm{FSBM}$ \\
\hline Feed intake during lactation, $\mathrm{kg} \cdot \mathrm{d}^{-1}$ & $5.43 \pm 0.12^{\mathrm{B}}$ & $5.08 \pm 0.30^{\mathrm{A}}$ & $5.64 \pm 0.32^{\mathrm{BC}}$ & $5.93 \pm 0.20^{\mathrm{C}}$ \\
Number of piglets at birth & $10.60 \pm 1.82$ & $11.75 \pm 1.71$ & $10.75 \pm 2.44$ & $11.75 \pm 2.05$ \\
Number of alive piglets at birth & $9.80 \pm 1.64$ & $10.75 \pm 1.71$ & $10.13 \pm 1.55$ & $11.38 \pm 1.77$ \\
Piglet survive rate at birth, $\%$ & $92.90 \pm 6.96$ & $91.97 \pm 11.80$ & $95.58 \pm 8.28$ & $97.16 \pm 3.94$ \\
Litter weight at birth, $\mathrm{kg}$ & $15.10 \pm 2.77$ & $16.63 \pm 1.38$ & $16.56 \pm 1.80$ & $16.85 \pm 1.33$ \\
Piglet weight at birth, $\mathrm{kg}$ & $1.43 \pm 0.15$ & $1.44 \pm 0.26$ & $1.59 \pm 0.25$ & $1.46 \pm 0.22$ \\
Interval between ablactation and oestrus, $\mathrm{d}$ & $6.60 \pm 0.89$ & $5.75 \pm 0.96$ & $5.13 \pm 0.83$ & $5.38 \pm 1.06$ \\
Number of weaning piglets & $7.91 \pm 1.73^{\mathrm{A}}$ & $9.71 \pm 0.50^{\mathrm{B}}$ & $9.98 \pm 0.99^{\mathrm{B}}$ & $10.13 \pm 1.06^{\mathrm{B}}$ \\
Weaning litter weight, $\mathrm{kg}$ & $62.30 \pm 8.91^{\mathrm{A}}$ & $71.88 \pm 8.29^{\mathrm{AB}}$ & $74.13 \pm 4.88^{\mathrm{AB}}$ & $77.75 \pm 10.59^{\mathrm{B}}$ \\
Weaning body weight, $\mathrm{kg}$ & $7.88 \pm 0.53^{\mathrm{A}}$ & $7.40 \pm 0.30^{\mathrm{A}}$ & $7.43 \pm 0.41^{\mathrm{A}}$ & $6.68 \pm 0.53^{\mathrm{A}}$ \\
Weaning survive rate, \% & $80.75 \pm 6.85^{\mathrm{A}}$ & $90.33 \pm 9.07^{\mathrm{B}}$ & $98.50 \pm 3.67^{\mathrm{C}}$ & $89.00 \pm 7.25^{\mathrm{B}}$ \\
Piglet daily gain, $\mathrm{kg}$ & $0.22 \pm 0.02$ & $0.25 \pm 0.01$ & $0.23 \pm 0.02$ & $0.26 \pm 0.02$ \\
Diarrhoea incidences during suckling, \% & $9.58 \pm 3.78$ & $7.76 \pm 1.33$ & $8.31 \pm 1.71$ & $8.02 \pm 2.24$ \\
\hline
\end{tabular}

each value represents mean \pm SE of 8 replicates per treatment; ${ }^{A B C}$ means with different superscipts within a row are significantly different at $P<0.05$, while values with no capital letters or the same letters mean no significant difference $(P>0.05)$

Table 4. Effects of FSBM on nutrient and minerals digestibility of lactating sows, \%

\begin{tabular}{|c|c|c|c|c|}
\hline Indices & Control group & $5 \%$ FSBM & $10 \%$ FSBM & $15 \%$ FSBM \\
\hline Crude protein & $87.5 \pm 1.49^{A}$ & $90.5 \pm 1.52^{\mathrm{B}}$ & $90.8 \pm 1.11^{\mathrm{B}}$ & $92.5 \pm 1.06^{c}$ \\
\hline Ether extract & $68.5 \pm 1.38^{A}$ & $78.4 \pm 4.46^{B}$ & $81.3 \pm 4.8^{\mathrm{B}}$ & $79.8 \pm 4.65^{\mathrm{B}}$ \\
\hline $\mathrm{Ca}$ & $52.6 \pm 1.83^{A}$ & $60.2 \pm 2.62^{\mathrm{B}}$ & $61.6 \pm 3.84^{\mathrm{B}}$ & $72.0 \pm 4.58^{c}$ \\
\hline$P$ & $65.2 \pm 2.65^{\mathrm{A}}$ & $69.7 \pm 1.78^{\mathrm{B}}$ & $71.0 \pm 3.83^{\mathrm{B}}$ & $79.1 \pm 3.26^{c}$ \\
\hline
\end{tabular}

each value represents mean \pm SE of 5 replicates per treatment; ${ }^{A B C}$ - see Table 3

Table 5. Effects of FSBM on milk compositions of lactating sows, $\mathrm{g} \cdot 100 \mathrm{ml}^{-1}$

\begin{tabular}{|c|c|c|c|c|}
\hline Indices & Control group & $5 \%$ FSBM & $10 \%$ FSBM & $15 \%$ FSBM \\
\hline Protein & $5.78 \pm 0.24$ & $6.74 \pm 0.79$ & $6.50 \pm 0.50$ & $6.49 \pm 0.53$ \\
\hline Fat & $4.34 \pm 0.34$ & $6.05 \pm 0.73$ & $5.49 \pm 0.79$ & $4.93 \pm 0.37$ \\
\hline Lactose & $2.32 \pm 0.14$ & $2.48 \pm 0.37$ & $2.41 \pm 0.09$ & $2.71 \pm 0.24$ \\
\hline Non-fat milk solid & $9.37 \pm 0.38^{A}$ & $9.68 \pm 0.24^{\mathrm{A}}$ & $9.62 \pm 0.51^{\mathrm{A}}$ & $11.26 \pm 0.63^{\mathrm{B}}$ \\
\hline
\end{tabular}

each value represents mean \pm SE of 5 replicates per treatment; ${ }^{A B C}-$ see Table 3

Table 6. Effects of fermented FSBM on serum biochemical parameters of lactating sows

\begin{tabular}{|c|c|c|c|c|}
\hline Serum biochemical parameters & Control group & $5 \%$ FSBM & $10 \%$ FSBM & $15 \%$ FSBM \\
\hline \multicolumn{5}{|l|}{ Concentration } \\
\hline total protein, $\mathrm{g} \cdot \mathrm{I}^{-1}$ & $79.00 \pm 8.26$ & $73.18 \pm 5.42$ & $74.68 \pm 2.76$ & $75.00 \pm 3.03$ \\
\hline glucose, $\mathrm{mmol} \cdot \mathrm{I}^{-1}$ & $0.19 \pm 0.01$ & $0.17 \pm 0.02$ & $0.19 \pm 0.02$ & $0.19 \pm 0.02$ \\
\hline triglycerides, $\mathrm{mmol} \cdot \mathrm{I}^{-1}$ & $0.29 \pm 0.06$ & $0.21 \pm 0.06$ & $0.19 \pm 0.06$ & $0.19 \pm 0.05$ \\
\hline total cholesterol, $\mathrm{mmol} \cdot \mathrm{I}^{-1}$ & $2.20 \pm 0.13^{c}$ & $1.68 \pm 0.25^{\mathrm{AB}}$ & $1.43 \pm 0.17^{\mathrm{A}}$ & $1.81 \pm 0.11^{\mathrm{B}}$ \\
\hline urea nitrogen, $\mathrm{mmol} \cdot \mathrm{I}^{-1}$ & $6.06 \pm 0.33^{B}$ & $4.82 \pm 0.61^{\mathrm{A}}$ & $3.99 \pm 0.49^{A}$ & $4.55 \pm 0.25^{A}$ \\
\hline creatinine,$\mu \mathrm{mol} \cdot \mathrm{I}^{-1}$ & $197.25 \pm 13.57$ & $201.25 \pm 44.89$ & $212.75 \pm 58.06$ & $203.50 \pm 27.40$ \\
\hline $\operatorname{lgG}^{1},\left.g \cdot\right|^{-1}$ & $3.85 \pm 0.32$ & $3.90 \pm 0.35$ & $3.86 \pm 0.27$ & $3.99 \pm 0.09$ \\
\hline $\lg A^{2}, g \cdot l^{-1}$ & $0.02 \pm 0.01$ & $0.02 \pm 0.01$ & $0.02 \pm 0.00$ & $0.02 \pm 0.01$ \\
\hline $\operatorname{lgM}^{3}, g \cdot \mathrm{l}^{-1}$ & $1.26 \pm 0.27$ & $1.14 \pm 0.24$ & $1.13 \pm 0.09$ & $1.08 \pm 0.16$ \\
\hline prolactin, $\mathrm{ng} \cdot \mathrm{ml}^{-1}$ & $3.40 \pm 0.16^{\mathrm{A}}$ & $4.08 \pm 0.22^{B}$ & $4.35 \pm 0.17^{c}$ & $4.39 \pm 0.19^{c}$ \\
\hline $\mathrm{GSH}^{4}, \mathrm{~mol} \cdot \mathrm{ml}^{-1}$ & $843.26 \pm 32.97^{\mathrm{A}}$ & $971.74 \pm 23.70^{c}$ & $1076.10 \pm 8.45^{\mathrm{D}}$ & $910.76 \pm 5.17^{\mathrm{B}}$ \\
\hline \multicolumn{5}{|l|}{ Activity } \\
\hline phosphocreatine kinase, $U \cdot I^{-1}$ & $827.00 \pm 93.18^{B}$ & $463.33 \pm 69.33^{A}$ & $728.00 \pm 171.79^{\mathrm{AB}}$ & $534.00 \pm 154.69^{A}$ \\
\hline alanine aminotransferase, $\mathrm{U} \cdot \mathrm{I}^{-1}$ & $37.00 \pm 5.94$ & $33.00 \pm 1.83$ & $29.00 \pm 2.58$ & $31.00 \pm 4.69$ \\
\hline aspartate aminotransferase, $\mathrm{U} \cdot \mathrm{I}^{-1}$ & $55.75 \pm 6.29^{B}$ & $33.00 \pm 3.92^{\mathrm{A}}$ & $37.75 \pm 8.06^{\mathrm{A}}$ & $36.00 \pm 9.66^{A}$ \\
\hline $\mathrm{SOD}^{5}, \mathrm{U} \cdot \mathrm{ml}^{-1}$ & $77.04 \pm 2.16^{A}$ & $86.54 \pm 1.25^{\mathrm{B}}$ & $90.47 \pm 1.16^{\mathrm{C}}$ & $87.97 \pm 0.92^{\mathrm{BC}}$ \\
\hline \multicolumn{5}{|l|}{ Other } \\
\hline $\mathrm{T}_{-} \mathrm{AOC} \mathrm{C}^{6}, \mathrm{U} \cdot \mathrm{ml}^{-1}$ & $5.43 \pm 0.33^{\mathrm{A}}$ & $5.59 \pm 0.19^{A}$ & $8.55 \pm 0.40^{C}$ & $87.52 \pm 0.33^{B}$ \\
\hline
\end{tabular}

${ }^{1} \mathrm{lgG}$ - immunoglobulin $\mathrm{G} ;{ }^{2} \mathrm{lgA}$ - immunoglobulin $\mathrm{A} ;{ }^{3} \mathrm{lgM}$ - immunoglobulin $\mathrm{M} ;{ }^{4} \mathrm{GSH}$ - glutathione; ${ }^{5} \mathrm{SOD}$ - superoxide dismutase; ${ }^{6} \mathrm{~T}$-AOC - total antioxidant capacity; each value represents mean \pm SE of 5 replicates per treatment; ${ }^{A B C}-$ see Table 3 
Table 7. Effects of FSBM on microbial counts and enzyme activity in faeces of lactating sows

\begin{tabular}{|c|c|c|c|c|}
\hline Indices & Control group & $5 \%$ FSBM & $10 \%$ FSBM & $15 \%$ FSBM \\
\hline \multicolumn{5}{|l|}{ Content } \\
\hline lactic acid bacteria, CFU $\cdot \mathrm{g}^{-1}$ & $7.94 \pm 0.25^{\mathrm{A}}$ & $8.66 \pm 0.24^{B}$ & $8.75 \pm 0.29^{B}$ & $8.99 \pm 0.19^{\mathrm{B}}$ \\
\hline Escherichia coli, CFU $\cdot \mathrm{g}^{-1}$ & $6.40 \pm 0.91$ & $6.43 \pm 0.77$ & $6.52 \pm 0.86$ & $6.78 \pm 0.69$ \\
\hline \multicolumn{5}{|l|}{ Activity } \\
\hline protease, $\mathrm{U} \cdot \mathrm{g}^{-1}$ & $28.73 \pm 4.68^{\mathrm{A}}$ & $27.12 \pm 1.29^{A}$ & $32.86 \pm 2.89^{A}$ & $60.92 \pm 7.62^{\mathrm{B}}$ \\
\hline amylase, $\mathrm{U} \cdot \mathrm{g}^{-1}$ & $12.78 \pm 0.72$ & $13.82 \pm 1.25$ & $13.68 \pm 1.40$ & $12.92 \pm 0.32$ \\
\hline lipase, $\mathrm{U} \cdot \mathrm{g}^{-1}$ & $5.41 \pm 1.18$ & $5.96 \pm 1.13$ & $8.08 \pm 1.22$ & $7.13 \pm 0.84$ \\
\hline
\end{tabular}

${ }^{1} \mathrm{CFU}$ - colony forming units; each value represents mean \pm SE of 5 replicates per treatment; ${ }^{\mathrm{ABC}}$ - see Table 3

\section{Microbes and enzyme activity in faeces}

FSBM addition significantly increased the counts of lactic acid bacteria in sow faeces $(P<0.05)$, but it had no significant effect on $E$. coli counts $(P>0.05)$, when compared with the control group (Table 7). What is more, $15 \%$ FSBM addition significantly increased faecal protease activity group $(P<0.05)$, when compared with other three groups; however, three levels of FSBM additions had no significant effect on faecal amylase and lipase activities $(P>0.05)$.

\section{Discussion}

To remove the antinutritional factors and improve biological values of soyabean meal (SBM), many species of microbes such as lactic acid bacteria (Cho et al., 2007) and Bacillus subtilis (Kiers et al., 2003) have been used for fermenting SBM. This result indicated that SBM fermented with the optimal microbial proportions could reduce antigen protein by enzymatic hydrolysis and microbial fermentation as well as increase protein, lactic acid, probiotics, acid-soluble protein, total and most amino acid contents in fermented soyabean meal (FSBM), which is in agreement with previous reports (Hachmeister and Fung, 1993; Zhao et al., 2008). The higher contents of crude protein, most amino acids and other nutrients in FSBM are due to microbial protein synthesis and organic matter loss during microbial fermentation. It was reported that oligosaccharides were totally removed, non-reducing polysaccharides were decreased by $67 \%$, and protein content was increased by $9.5 \%$ after SBM microbial fermentation (Chen et al., 2014), corresponding to this result.

There are some reports about FSBM application in piglets (Kiers et al., 2003; Feng et al., 2007; Lee et al., 2007; Song et al., 2010); however, few reports can be found for its application in sow's reproduction.

The present results showed that replacing SBM by FSBM in lactating sow's diets improved the apparent digestibility of crude protein, ether extract, calcium and phosphorus, due to enzymatic hydrolyses and microbial fermentation in vivo and in vitro (Zhao et al., 2008). The good production performances of piglets such as lower mortality and higher weaning litter weight in 3 FSBM groups may be due to the existence of the maternal effects from the high biological value of FSBM for sows.

Prolactin promotes both the growth and differentiation of the mammary epithelium for milk excretion, so higher blood serum prolactin concentration of sows may increase milk production and piglet growth (Vanklompenberg et al., 2013). This study showed a higher serum prolactin concentration in the lactating sows fed diet containing 5-15\% FSBM, inferring that milk excretion would be improved to increase growth and weaning survival rates for suckling piglets. In addition, the composition of milk is also very important for piglet growth (Kim and $\mathrm{Wu}, 2009)$. This research showed that the contents of milk protein, fat and lactose were not improved by FSBM addition; however, the non-fat milk solid was significantly increased by $15 \%$ FSBM addition. The higher growth and lower piglets mortality from the sows fed with FSBM may be due to the maternal effects of higher milk excretion and better milk composition, especially for $15 \%$ FSBM addition, maybe due to the high concentration of FSBM in sow diet.

Blood urea nitrogen (BUN) is a very sensitive index to evaluate amino acid requirement and protein metabolism of animals. It was reported that BUN concentration was decreased if dietary amino acid was well balanced (Malmlof, 1988). In this study, replacing SBM by FSBM in lactating sow diet decreased BUN concentration, which means that biological value of FSBM is better than SBM, and is in agreement with the previous research (Xu et al., 2012). The lower serum urea nitrogen may be due to the higher digestibility of protein and amino acids in FSBM (Jeong et al., 2015). In addition, the lower serum contents of phosphocreatine kinase and aspartate aminotransferase caused by FSBM addition indicate that FSBM may be able to protect cells from damages, which will benefit sow's health. 
Fukushima and Nakano (1996) reported that rats fed with Lactobacillus acidophilus could reduce serum cholesterol content. In this study, replacing SBM by FSBM decreased the total cholesterol concentration in serum of the lactating sows, probably due to the high content of lactic acid bacteria in FSBM. The high counts of lactic acid bacteria in faeces of sows fed with FSBM support the above mentioned hypothesis. This study showed that FSBM could increase serum T-AOC, SOD activity and GSH content of lactating sows, indicating that FSBM can increase sow's antioxidant capacity which can improve sow's health. However, the immunological parameters (serum IgA, IgM and IgG contents) were not influenced by FSBM addition.

Also, this study indicated that $15 \%$ FSBM addition increased faecal protease activity of lactating sows. The reason is that the FSBM rich in Bacillus subtilis can secrete more protease. Feng et al. (2007) proved that the activities of total protease and trypsin at the duodenum and jejunum of piglets fed with FSBM increased.

\section{Conclusions}

This study showed that replacing soyabean meal by $10-15 \%$ fermented soyabean meal in lactating sow diets increases significantly nutrients digestibility and biological value, improves serum biochemical parameters and antioxidant activity of lactating sows, and increases suckling piglet production performance.

\section{Acknowledgments}

This study was supported by the Program for Innovative Research Team (in Science and Technology) in University of Henan Province, China, Grant No. 15IRTSTHN014.

\section{References}

AOAC International, 2011. Official Methods of Analysis of AOAC International. Current Through Revision 4. $18^{\text {th }}$ Edition. Gaithersburg, MD

Atkinson J.L., Hilton J.W., Slinger S.J., 1984. Evaluation of acid-insoluble ash as an indicator of feed digestibility in rainbow trout (Salmo gairdneri). Can. J. Fisheries Aquat. Sci. 41, 1384-1386

Baker K.M., Kim B.G., Stein H.H., 2010. Amino acid digestibility in conventional, high-protein, or low-oligosaccharide varieties of full-fat soybeans and in soybean meal by weanling pigs. Anim. Feed Sci. Tech. 162, 66-73

Chen L., Vadlani P.V., Madl R.L., 2014. High-efficiency removal of phytic acid in soy meal using two-stage temperature-induced Aspergillus oryzae solid-state fermentation. J. Sci. Food Agric. 94, 113-118
Cho J.H., Min B.J., Chen Y.J., Yoo J.S., Wang Q., Kim J.D., Kim I.H., 2007. Evaluation of FSP (fermented soy protein) to replace soybean meal in weaned pigs: growth performance, blood urea nitrogen and total protein concentrations in serum and nutrient digestibility. Asian-Austral. J. Anim. Sci. 20, 1874-1879

Erlanson-Albertsson C., Larsson A., Duan R., 1987. Secretion of pancreatic lipase and colipase from rat pancreas. Pancreas $2,531-535$

Fan C.G., 2013. Study on the fermented soybean meal with microbes and its application in sow production. Master Thesis, Henan Agricultural University. Zhengzhou (China)

Feng J., Liu X., Xu Z.R., Lu Y.P., Liu Y.Y., 2007. The effect of Aspergillus oryzae fermented soybean meal on growth performance, digestibility of dietary components and activities of intestinal enzymes in weaned piglets. Anim. Feed Sci. Tech. 134, 295-303

Fukushima M., Nakano M., 1996. Effects of a mixture of organisms, Lactobacillus acidophilus or Streptococcus faecalis on cholesterol metabolism in rats fed on a fat- and cholesterolenriched diet. Brit. J. Nutr. 76, 857-867

GaoY.-L., Wang C.-S., Zhu Q.-H., Qian G.-Y., 2013. Optimization of solidstate fermentation with Lactobacillus brevis and Aspergillus oryzae for trypsin inhibitor degradation in soybean meal. J. Integr. Agr. 12, 869-876

Hachmeister K.A., Fung D.Y., 1993. Tempeh: a mold-modified indigenous fermented food made from soybeans and/or cereal grains. Crit. Rev. Microbiol. 19, 137-188

Hartemink R., Domenech V.R., Rombouts F.M., 1997. LAMVAB - a new selective medium for the isolation of lactobacilli from faeces. J. Microbiol. Meth. 29, 77-84

Jeong J.S., Park J.W., Lee S.I., Kim I.H., 2015. Apparent ileal digestibility of nutrients and amino acids in soybean meal, fish meal, spray-dried plasma protein and fermented soybean meal to weaned pigs. Anim. Sci. J. doi: 10.1111/asj.12483

Jurgens M.H., 1997. Animal Feeding and Nutrition. $8^{\text {th }}$ Edition. Kendall/ Hunt Publishing Company. Dubuque, IA (USA)

Kiers J.L., Meijer J.C., Nout M.J.R., Rombouts F.M., Nabuurs M.J.A., van der Meulen J., 2003. Effect of fermented soya beans on diarrhoea and feed efficiency in weaned piglets. J. Appl. Microbiol. 95, 545-552

Kim S.W., Wu G., 2009. Regulatory role for amino acids in mammary gland growth and milk synthesis. Amino Acids 37, 89-95

Lee J.O., Park M.H., Choi Y.H., Ha Y.L., Ryu C.H., 2007. New fermentation technique for complete digestion of soybean protein. J. Microbiol. Biotechnol. 17, 1904-1907

Li D.F., Nelssen J.L., Reddy P.G., Blecha F., Klemm R., Goodband R.D., 1991. Interrelationship between hypersensitivity to soybean proteins and growth performance in early-weaned pigs. J. Anim. Sci. 10, 4062-4069

Lynn K.R., Clevette-Radford N.A., 1984. Purification and characterization of hevain, a serine protease from Hevea brasiliensis. Phytochemistry 23, 963-964

Malmlof K., 1988. Amino acid in farm animal nutrition metabolism, partition and consequences of imbalance. Swed. J. Agr. Res. 18, 191-193

McCarthy J.F., Aherne F.X., Okai D.B., 1974. Use of $\mathrm{HCl}$ insoluble ash as an index material for determining apparent digestibility with pigs. Can. J. Anim. Sci. 54, 107-109

NRC, 1998. Nutrient Requirements of Swine. $10^{\text {th }}$ revised Edition. National Academic Press, Washington, DC

Rick W., Stegbauer H.P., 1974. Amylase measurement of reducing groups, In: H.V. Bergmeyer (Editor). Methods of Enzymatic Analysis, Vol. 2. $2^{\text {nd }}$ Edition. Academic Press, New York (USA) 
Shapton D.A., Board R.G. (Editors), 1971. Isolation of Anaerobes. (The Society for Applied Bacteriology, Technical Series, No. 5) Academic Press, London - New York

Song Y.S., Pérez V.G., Pettigrew J.E., Martinez-Villaluenga C., Gonzalez de Mejia E., 2010. Fermentation of soybean meal and its inclusion in diets for newly weaned pigs reduced diarrhea and measures of immunoreactivity in the plasma. Anim. Feed Sci. Tech. 159, 41-49

Teng D., Gao M.Y., Yang Y.L., Liu B., Tian Z.G., Wang J.H., 2012. Biomodification of soybean meal with Bacillus subtilis or Aspergillus oryzae. Biocatal. Agr. Biotechnol. 1, 32-38

Vanklompenberg M.K., Manjarin R., Trott J.F., McMicking H.F., Hovey R.C., 2013. Late gestational hyperprolactinemia accelerates mammary epithelial cell differentiation that leads to increased milk yield. J. Anim. Sci. 91, 1102-1111
Xu F.Z., Li L.M., Liu H.J., Zhan K., Qian K., Wu D., Ding X.L., 2012. Effects of fermented soybean meal on performance, serum biochemical parameters and intestinal morphology of laying hens. J. Anim. Vet. Adv. 11, 649-654

Yen J.T., Jensen A.H., Simon J., 1977. Effect of dietary raw soybean and soybean trypsin inhibitor on trypsin and chymotrypsin activities in the pancreas and in small intestinal juice of growing swine. J. Nutr. 107, 156-165

Yin Q.Q., Zheng Q.H., Kang X.T., 2007. Biochemical characteristics of phytases from fungi and the transformed microorganism. Anim. Feed Sci. Tech. 132, 341-350

Zhao Y., Qin G., Sun Z., Zhang X., Bao N., Wang T., Zhang B., Zhang B., Zhu D., Sun L., 2008. Disappearance of immunoreactive glycinin and $\beta$-conglycinin in the digestive tract of piglets. Arch. Anim. Nutr. 62, 322-330 